\title{
ANALISIS PERANGKAT PEMBELAJARAN \\ BERBASIS HIGHER ORDER THINKING SKILL (HOTS) \\ DI MASA PANDEMI COVID-19
}

\author{
Euis Vera Nursari ${ }^{1}$, Ina Setiawati ${ }^{2}$, Lilis Lismaya ${ }^{3}$ \\ Program Studi Pendidikan Biologi, FKIP Universitas Kuningan, Jl. Cut Nyak Dhien No. 36 A \\ Cijoho - Kuningan \\ E-mail ${ }^{l}$ : euisveranursari@gmail.com
}

DOI : 10.35719/alveoli.v2i2.52

\begin{abstract}
Higher order thinking skill (HOTS)-based learning tools prepared by teachers are often not optimally prepared in learning activities, especially in online learning, so there are still many teachers who are not optimal in compiling higher order thinking skill (HOTS)-based learning tools. This study aims to analyze (1) the Learning Process Plan (RPP) based on higher order thinking skills (HOTS) during the covid-19 pandemic, (2) the implementation of learning based on higher order thinking skills (HOTS) during the covid-19 pandemic. , (3) evaluation of higher order thinking skill (HOTS) based learning during the covid-19 pandemic. The type of research used is descriptive qualitative. The research subject is a biology teacher in class XI of SMAN 2 Kuningan. The object of research includes lesson plans, implementation of learning, and evaluation of learning. Data collection techniques consist of observation and documentation. Data analysis through credibility test, transferability test, dependability test, and confirmability test. The results of this study indicate that (1) the Learning Process Plan (RPP) is based on higher order thinking skills (HOTS) during the covid-19 pandemic with a good category, (2) the implementation of learning is based on higher order thinking skills (HOTS) during the pandemic. covid-19 with a very good category, (3) the evaluation of learning has been based on higher order thinking skills (HOTS) during the covid-19 pandemic with a good category.
\end{abstract}

Keywords: Higher Order Thinking Skill (HOTS), learning tools, online learning.

\begin{abstract}
Abstrak : Perangkat pembelajaran berbasis higher order thinking skill (HOTS) yang disusun oleh guru sering kali tidak dipersiapkan secara maksimal dalam kegiatan pembelajaran terutama dalam pembelajaran daring, sehingga masih banyak guru yang belum maksimal dalam menyusun perangkat pembelajaran berbasis higher order thinking skill (HOTS). Penelitian ini bertujuan untuk menganalisis (1) Rencana Proses Pembelajaran (RPP) yang berbasis higher order thinking skill (HOTS) di masa pandemi covid-19, (2) pelaksanaan pembelajaran yang berbasis higher order thinking skill (HOTS) di masa pandemi covid-19, (3) evaluasi pembelajaran berbasis higher order thinking skill (HOTS) di masa pandemi covid-19. Jenis penelitian yang digunakan adalah kualitatif deskriptif. Subjek penelitiannya guru biologi kelas XI SMAN 2 Kuningan. Objek penelitian meliputi RPP, pelaksanaan pembelajaran, dan evaluasi pembelajaran. Teknik pengumpulan data terdiri observasi dan dokumentasi. Analisis data melalui uji credibility, uji transferability, uji dependability, dan uji confirmability. Hasil penelitian ini menunjukkan bahwa (1) Rencana Proses Pembelajaran (RPP) sudah berbasis higher order thinking skill (HOTS) di masa pandemi covid-19 dengan kategori baik, (2) pelaksanaan pembelajaran sudah berbasis higher order thinking skill (HOTS) di masa pandemi covid-19 dengan kategori sangat baik, (3) evaluasi pembelajaran sudah berbasis higher order thinking skill (HOTS) di masa pandemi covid-19 dengan kategori baik.
\end{abstract}

Kata Kunci : Higher Order Thinking Skill (HOTS), perangkat pembelajaran, pembelajaran daring. 
Pembelajaran dapat diartikan sebagai kegiatan yang memiliki peran penting dalam memajukan dunia pendidikan. Dalam melaksanakan pembelajaran,terlebih dahulu guru harus memiliki persiapan dan rencana yang matang agar pembelajaran dapat terlaksana dengan baik, diantaranya guru harus mempersiapkan perangkat pembelajaran.Perangkat pembelajaran merupakan hal penting yang harus disusun dan dipersiapkan oleh guru sebelum memasuki proses pembelajaran. Perangkat pembelajaran merupakan suatu alat perlengkapan yang dipersiapkan oleh guru untuk melakukan kegiatan pembelajaran dan berperan sebagai pegangan guru dalam melaksanakan pembelajaran dikelas (Sari et al., 2020). Perangkat pembelajaran meliputi tahap perencanaan pembelajaran (RPP), tahap pelaksanaan pembelajaran, dan tahap evaluasi pembelajaran. Perencanaan pembelajaran (RPP) merupakan suatu kegiatan menyusun langkahlangkah yang akan dilaksanakan dan memiliki tujuan yang akan dicapai serta dibuat dengan berdasarkan kebutuhan dan dapat dilaksanakan dengan mudah dan tepat (Majid, 2013).

Pelaksanaan pembelajaran meliputi tahapan pendahuluan, tahapan inti,dan tahapan penutup yaitu dari awal guru membuka pelajaran sampai guru menutup pelajaran. Dalam pelaksanaan pembelajaran guru dapat melatih siswa untuk berpikir tingkat tinggi. Salah satu cara melatih keterampilan berpikir tingkat tinggi untuk siswa yaitu dengan pembelajaran berbasis masalah, pendekatan saintifik, dan pembuatan evaluasi berbasis masalah. Perangkat pembelajaran yang dapat melatih keterampilan berpikir tingkat tinggi bagi siswa harus memuat aspek-aspek keterampilan berpikir tingkat tinggi. Aspek-aspek tersebut harus terdapat dalam tahap perencanaan proses pembelajaran, pelaksanaan proses pembelajaran, serta evaluasi proses pembelajaran (Helmawati,2019).

Evaluasi pembelajaran pada kurikulum 2013 umumnya menilai 3 ranah penilaian, yaitu ranah kognitif, ranah afektip, dan ranah psikomotorik. Menurut Sulistiawan et al (2017) menyatakan bahwa evaluasi pembelajaran yang dilaksanakan oleh guru meliputi 3 aspek, yaitu aspek kognitif dalam bentuk tes tertulis dan tes lisan, aspek afektip dalam bentuk penilaian observasi sikap, dan aspek psikomotorik dalam bentuk portofolio penilaian keterampilan siswa. Hal ini menunjukkan bahwa perangkat pembelajaran memiliki peranan yang sangat penting dalam proses pembelajaran, yaitu dengan diawali adanya tahap perencanaan yang dipersiapkan oleh guru, tahap pelaksanaan pada proses pembelajaran dan tahap evaluasi diakhir pembelajaran. Dengan adanya perangkat pembelajaran, maka proses pembelajaran akan terlaksana dengan baik 
dan teratur. Pembelajaran yang baik adalah pembelajaran yang sudah direncanakan dan memiliki tujuan yang jelas dan mampu menanamkan karakter dan motivasi kepada siswa, maka dari itu perangkat pembelajaran sangat diperlukan oleh guru sebelum melaksanakan pembelajaran di kelas (Setyorini \& Izzati,2016).

Dalam kurikulum 2013 siswa dituntut untuk meningkatkan kemampuan berpikir dari tahap Low Order Thinking Skill (LOTS) yang meliputi aspek mengingat (C1), memahami (C2), dan menerapkan (C3), menuju High Order Thinking Skill (HOTS) yang meliputi aspek menganalisis (C4), mengevaluasi (C5) dan mencipta (C6) (Anderson \& Krathwohl, 2015). Pembelajaran yang berorientasi pada keterampilan berpikir tingkat tinggi merupakan suatu program pemerintah yang dikembangkan sebagai upaya Kemendikbud melalui Direktorat Jendral Guru dan Tenaga Kependidikan (Ditjen GTK) untuk peningkatan kualitas dan mutu pembelajaran serta kualitas lulusan yang lebih baik (Ariyana et al.,2018). Hal ini menunjukkan bahwa pembelajaran yang dilaksanakan disekolah harus lebih ditingkatkan dan perlu dibiasakan melatih keterampilan berpikir tingkat tinggi pada siswa melalui perangkat pembelajaran yang disusun oleh guru.

Meningkatnya kasus pandemi Covid-19 di Indonesia, maka pemerintah membuat surat edaran mengenai pembelajaran yang dilaksanakan secara jarak jauh. Berdasarkan Surat Edaran Mendikbud No. 04 Tahun 2020 tentang pelaksanaan kebijakan pendidikan dalam masa darurat penyebaran covid-19, menghimbau agar semua lembaga pendidikan tidak melakukan proses belajar mengajar secara tatap muka, melainkan melalui pembelajaran jarak jauh (Mendikbud, 2020). Pembelajaran jarak jauh memiliki berbagai dampak bagi dunia pendidikan, baik bagi siswa maupun bagi guru. Salah satu kekurangan dari pembelajaran jarak jauh adalah kurangnya interaksi antara guru dan siswa, serta hambatan lain yang dapat disebabkan oleh sistem misalnya pengaruh signal atau jaringan (Hadisi \& Muna, 2015).

Dengan diberlakukannya pembelajaran daring, maka banyak pihak sekolah yang menggunakan media sosial sebagai alat dalam melaksanakan pembelajaran. Begitupun dengan sekolah SMAN 2 Kuningan yang menggunakan aplikasi CloudX dalam pelaksanaan pembelajarannya. Melalui aplikasi CloudX guru dapat bertatap maya dengan siswa, menjelaskan materi, dan memberikan tugas seperti pembelajaran yang biasa dilaksanakan dikelas tatap muka. Adanya perubahan proses pembelajaran dari tatap muka menjadi daring atau jarak jauh, tentunya hal ini seharusnya bukan menjadi alasan guru untuk tidak memfasilitasi HOTS (Higher Order Thinking Skill) siswa dalam pembelajaran daring. Guru harus tetap membuat RPP yang dapat 
memfasilitasi dan melatih HOTS siswa agar dalam proses pembelajaran dan evaluasi nya sesuai dengan tujuan pembelajaran dan mencapai tuntutan kurikulum 2013.

Namun hal ini tidak menutup kemungkinan adanya berbagai hambatan baik itu dari guru atau dari siswa. Permasalahan yang ditemukan dari guru yaitu masih adanya guru yang kurang mempersiapkan perangkat pembelajaran ketika akan melaksanakan pembelajaran dikelas, kurangnya fasilitas media pembelajaran yang mendukung terlaksananya pembelajaran, permasalahan jaringan yang hampir sama dengan masalah yang dialami oleh siswa. Pada penelitian difokuskan pada perangkat pembelajaran yang disusun dan dipersiapkan oleh guru dalam melaksanakan pembelajaran daring yang meliputi RPP, pelaksanaan pembelajaran, dan evaluasi pembelajaran dalam memfasilitasi HOTS siswa. Peneliti melakukan analisis pada perangkat pembelajaran yang disusun oleh guru Biologi kelas XI SMAN 2 Kuningan untuk mengetahui apakah perangkat pembelajarannya sudah memfasilitasi HOTS dimasa pandemi ini atau belum.

Pelaksanaan penelitian akan dilaksanakan di kelas XI SMAN 2 Kuningan ini memiliki beberapa alasan, yang pertama penelitian tidak dilaksanakan di kelas X SMAN 2 Kuningan karena kelas X merupakan siswa baru yang belum mengalami pembelajaran HOTS dalam waktu yang cukup lama. Penelitian juga tidak dilaksanakan di kelas XII karena kelas XII SMAN 2 Kuningan pada saat itu sudah tidak ada proses pembelajaran dikarenakan sudah melaksanakan ujian. SMAN 2 Kuningan merupakan salah satu SMA unggulan yang memiliki segudang prestasi di Kabupaten Kuningan (Sidik et al., 2021). Pelaksanaan penelitian dilaksanakan di SMAN 2 Kuningan bertujuan untuk mengetahui bagaimana persiapan pembelajaran (perangkat pembelajaran) yang berbasis HOTS yang dilaksanakan di SMAN 2 Kuningan pada masa pandemi Covid-19.

Berdasarkan hasil observasi melalui wawancara dengan guru biologi kelas XI SMAN 2 Kuningan bahwa terdapat perbedaan kegiatan belajar antara pembelajaran daring dan pembelajaran tatap muka. Pada saat pembelajaran tatap muka, guru dapat melihat langsung proses yang dilakukan oleh siswa dalam menyelesaikan tugas atau soal evaluasi yang diberikan oleh guru. Dari mulai siswa menganalisis soal sampai ke tahap membuat solusi atau ide mengenai masalah yang terdapat soal tersebut dengan tetap berkomunikasi dengan guru. Jika ada yang tidak dipahami, siswa akan langsung bertanya kepada guru, sehingga siswa menjadi lebih paham mengenai maksud dan tujuan dari soal. Sedangkan dalam pembelajaran daring, guru tidak 
bisa melihat langsung proses yang dilakukan oleh siswa dalam menyelesaikan soal ataupun tugas. Hasil yang diterima oleh guru berupa jawaban tugas dan soal dari siswa. Sehingga guru kesulitan mengontrol pembelajaran yang dilakukan oleh siswa ketika daring. Begitupula dengan penyusunan perangkat pembelajaran yang dilakukan oleh guru harus disesuaikan dengan pembelajaran daring, namun beberapa guru tetap menyusun perangkat pembelajaran seperti biasa (Pembelajaran luring) tetapi digunakan dalam pembelajaran daring.

Kegiatan analisis pada perangkat pembelajaran penting dilaksanakan karena perangkat pembelajaran merupakan seperangkat rencana yang telah disusun dan dipersiapkan oleh guru sebelum melaksanakan pembelajaran hingga setelah pembelajaran. Terlebih di masa pandemi Covid-19 seperti saat ini yang banyak menggunakan pembelajaran secara daring, sehingga perlu dilakukan analisis apakah guru mempersiapkan perangkat pembelajaran dengan baik walaupun dalam pembelajaran daring. Tujuannya agar guru tetap konsisten dalam memfasilitasi HOTS siswa walaupun berada dalam masa pandemi Covid-19 pada RPP,pelaksanaan pembelajaran dan evaluasi pembelajaran, karena dunia pendidikan semakin berkembang sehingga diharapkan guru mampu membekali siswanya ilmu pengetahuan yang sesuai dengan tuntutan pendidikan dimasa sekarang dan masa depan.

\section{METODE}

Jenis penelitian yang digunakan adalah metode kualitatif deskriptif, yaitu untuk menuat deskripsi mengenai perangkat pembelajaran yang berbasis Higher Order Thinking Skill (HOTS) di masa pandemi covid-19 secara sistematis dan terperinci. Waktu penelitian dilaksanakan pada bulan April-Juni tahun 2021 di SMAN 2 Kuningan, Jawa Barat. Subjek penelitiannya adalah guru Biologi kelas XI SMAN 2 Kuningan, Jawa Barat. Objek penelitian yang digunakan meliputi RPP, kegiatan pembelajaran dikelas daring, dan evaluasi pembelajaran. Teknik pengambilan sampel dilakukan dengan cara purposive sampling, hal ini dilakukan atas pertimbangan tertentu yang sudah setujui oleh beberapa pihak yang terlibat yang meyakini sampel yang diambil tepat dan sesuai dengan penelitian yang diperlukan oleh peneliti (Sugiyono, 2016). Sehingga peneliti mengambil informan dari guru kelas XI SMAN 2 Kuningan sebagai sampel penelitian.

Sumber data dibagi menjadi 2, yaitu sumber data primer yang meliputi kegiatan observasi dikelas daring, dan sumber data sekunder berupa dokumen RPP dan evaluasi pembelajaran. Teknik pengumpulan data dilakukan dengan cara observasi dan dokumentasi. Analisis perangkat 
pembelajaran dilaksanakan dengan menggunakan instrument penelitian berupa lembar observasi dan rubrik observasi. Berikut adalah ringkasan format dari lembar observasi dan rubrik observasi yang digunakan oleh peneliti :

Tabel 1. Ringkasan Format lembar Observasi dan Rubrik Observasi

\begin{tabular}{|l|l|l|l|l|l|}
\hline No. & \multicolumn{1}{|c|}{ Dimensi } & Sangat Baik & Baik & $\begin{array}{c}\text { Cukup } \\
\text { Baik }\end{array}$ & $\begin{array}{c}\text { Kurang } \\
\text { Baik }\end{array}$ \\
\hline 1. & Rencana Pelaksanaan Pembelajaran (RPP) & & & & \\
\hline 2. & Pelaksanaan Pembelajaran & & & & \\
\hline 3. & Evaluasi Pembelajaran & & & & \\
\hline
\end{tabular}

Sumber : (Setiawati \& Hindriana, 2020)

Lembar observasi RPP berisi beberapa uraian dari RPP, yaitu indikator pencapaian kompetensi, tujuan pembelajaran, materi ajar, model dan metode, media pembelajaran, dan LKS. Lembar observasi pelaksanaan pembelajaran berisi uraian dari kegiatan pendahuluan, kegiatan inti, dan kegiatan penutup pembelajaran. Lembar observasi evaluasi pembelajaran berisi uraian dari soal evaluasi, nilai jawaban siswa, teknik dan instrument evaluasi, keterlaksanaan evaluasi, dan tindak lanjut pembelajaran. Rubrik observasi berisi tentang uraian-uraian dari setiap dimensi yang dinilai, yaitu uraian dari RPP, pelaksanaan pembelajaran, dan evaluasi pembelajaran yang disertai dengan kategori sangat baik, baik, cukup baik, dan kurang baik.

Uji keabsahan data meliputi uji credibility, uji transferability, uji dependability, dan uji confirmability. Analisis data dilakukan melalui data reduction, data display, dan conclusion drawing. Pada tahap data reduction, hasil data perangkat pembelajaran disekolah berjumlah sangat banyak, maka dilakukan reduksi data dengan mengkategorikan proses pembelajaran kedalam 3 dimensi, yaitu dimensi RPP, dimensi pelaksanaan pembelajaran, dan dimensi evaluasi pembelajaran. Pada tahap data display, hasil dari reduksi data menjadi 3 dimensi, yaitu RPP, pelaksanaan pembelajaran, dan evaluasi pembelajaran. Selanjutnya ketiga dimensi ini di analisis berdasarkan aspek keterampilan berpikir tingkat tinggi (HOTS). Kategori HOTS pada penelitian ini dilihat dari penggunaan Kata Kerja Operasional (KKO Taksonomi Bloom) C4-C6, kemampuan 4C (Critical Thinking, Creative Thinking, Collaborative, Communication), dan kegiatan saintific 5M (Mengamati, Menanya, Mengumpulkan Informasi, Mengasosiasi, dan Mengkomunikasikan). Pada tahap conclusion drawing, data yang sudah direduksi selanjutnya dideskripsikan hasil analisis dari setiap dimensi yang diobservasi mengenai aspek keterampilan berpikir tingkat tinggi pada RPP, pelaksanaan pembelajaran, dan evaluasi pembelajaran. 


\section{HASIL}

Berikut ini adalah hasil analisis dari perangkat pembelajaran yang berbasis HOTS dimasa pandemi Covid-19 :

Tabel 2.Analisis Rencana Proses Pembelajaran (RPP) yang berbasis HOTS di masa pandemi Covid-19

\begin{tabular}{|c|l|c|}
\hline No. & \multicolumn{1}{|c|}{ Indikator RPP } & Kategori HOTS \\
\hline 1. & Indikator Pencapaian Kompetensi (IPK) & Cukup Baik \\
\hline 2. & Tujuan Pembelajaran & Cukup Baik \\
\hline 3. & Materi Ajar & Baik \\
\hline 4. & Model dan metode pembelajaran & Baik \\
\hline 5. & Media pembelajaran & Cungat baik \\
\hline 6. & Lembar Kerja Siswa (LKS) & Cukup Baik \\
\hline
\end{tabular}

Berdasarkan tabel 2, RPP yang disusun oleh guru terdiri dari beberapa kategori HOTS. Indikator Pencapaian Kompetensi (IPK), tujuan pembelajaran dan LKS sama-sama berada dalam kategori cukup baik. Materi ajar dan model/metode pembelajaran berada dalam kategori baik, dan untuk media pembelajaran berada dalam kategori sangat baik. Hal ini menunjukkan bahwa guru sudah mampu dan sudah berusaha memfasilitasi HOTS siswa dalam RPP yang disusunnya di masa pandemi Covid-19.

Tabel 3. Analisis Proses pembelajaran yang berbasis HOTS di masa pandemi Covid-19

\begin{tabular}{|l|l|c|}
\hline No. & \multicolumn{1}{|c|}{ Indikator Proses Pembelajaran } & Kategori HOTS \\
\hline 1. & Pendahuluan & Sangat baik \\
\hline 2. & Inti & Sangat baik \\
\hline 3. & Penutup & Sangat baik \\
\hline
\end{tabular}

Berdasarkan tabel 3, proses pembelajaran yang dilakukan oleh guru terdiri dari 3 tahapan, yaitu tahap pendahuluan, tahap inti, dan tahap penutup. 3 tahapan proses pembelajaran berada dalam kategori sangat baik, hal ini menunjukkan bahwa guru telah melaksanakan proses pembelajaran yang dapat memfasilitasi HOTS siswa dikelas daring pada masa pandemi Covid19.

Tabel 4. Analisis evaluasi pembelajaran yang berbasis HOTS di masa pandemi Covid-19

\begin{tabular}{|l|l|c|}
\hline No. & \multicolumn{1}{|c|}{ Indikator evaluasi pembelajaran } & Kategori HOTS \\
\hline 1. & Soal evaluasi & Cukup baik \\
\hline 2. & Nilai jawaban siswa & Baik \\
\hline 3. & Teknik dan instrument evaluasi & Sangat baik \\
\hline 4. & Keterlaksanaan evaluasi & Sangat baik \\
\hline 5. & Tindak lanjut pembelajaran & Cukup baik \\
\hline
\end{tabular}


Berdasarkan tabel 4, soal evaluasi dan tindak lanjut pembelajaran yang dibuat oleh guru berada dalam kategori cukup baik. Nilai jawaban siswa pada soal evaluasi yang diberikan oleh guru berada dalam kategori baik. Teknik dan instrument evaluasi serta keterlaksanaan evaluasi sudah berada dalam kategori sangat baik. Hal ini menunjukkan bahwa guru telah memfasilitasi evaluasi pembelajaran yang berbasis HOTS bagi siswa di masa pandemi Covid-19.

Pembelajaran yang berbasis HOTS tidak akan terlaksana jika dalam perangkat pembelajarannya, guru tidak memfasilitasi HOTS siswa. Pembelajaran yang berbasis HOTS dapat diterapkan oleh guru melalui perangkat pembelajaran yang disusunnya, yaitu dalam RPP, proses pembelajaran, dan evaluasi pembelajaran.

\section{PEMBAHASAN}

Penelitian ini berfokus pada analisis perangkat pembelajaran yang berbasis Higher Order Thinking Skill (HOTS) pada pembelajaran daring di masa pandemi Covid-19 di SMAN 2 Kuningan, Jawa Barat. Hasil yang diperoleh berupa deskripsi dari lembar observasi dengan berpedoman pada rubrik observasi. Deskripsi yang dibuat berdasarkan dari hasil obervasi di lapangan yang mendeskripsikan perangkat pembelajaran yang berbasis HOTS. Perangkat pembelajaran yang dianalisis adalah perangkat pembelajaran yang digunakan oleh guru biologi kelas XI SMAN 2 Kuningan di dalam pembelajaran daring melalui aplikasi CloudX disekolah. Penelitian ini sengaja dilakukan untuk menganalisis apakah dalam keadaan daring, guru masih memfasilitasi keterampilan berpikir tingkat tinggi siswa atau tidak. Pembelajaran daring ini dilakukan dengan tujuan untuk memutus rantai penyebaran virus Covid-19 di Indonesia, khususnya di daerah Kabupaten Kuningan, Jawa Barat. Sebagaimana edaran yang diterbitkan oleh Mendikbud Nomor 4 Tahun 2020 mengenai pembelajaran jarak jauh atau daring. Adanya pembelajaran daring, tentu memiliki pengaruh terhadap persiapan guru dalam melaksanakan pembelajaran dikelas. Namun, hal ini seharusnya tidak menjadi alasan guru dalam memfasilitasi siswa dikelas, guru harus tetap memberikan fasilitas belajar yang memadai bagi siswa walaupun berada dimasa pandemi Covid-19 seperti saat ini.

Perangkat pembelajaran yang dianalisis pada penelitian ini diantaranya adalah Rencana Pelaksanaan Pembelajaran (RPP) yang dapat dilihat pada (Tabel 2) bahwa terdapat 7 indikator RPP yang memuat nilai-nilai Higher Order Thinking Skill (HOTS) diantaranya adalah indikator pencapaian kompetensi (IPK), tujuan pembelajaran, materi ajar, model dan metode pembelajaran, media pembelajaran, langkah-langkah pembelajaran danl lembar kerja siswa 
(LKS). Rencana Pelaksanaan Pembelajaran (RPP) merupakan suatu acuan yang berperan penting bagi terlaksananya pembelajaran. Salah satu tujuan dari Rencana Pelaksanaan Pembelajaran (RPP) adalah untuk mempermudah guru dalam menyampaikan pembelajaran dan meningkatkan hasil belajar mengajar terhadap siswa. Dalam menyusun RPP, guru harus mampu mengembangkan RPP agar sesuai dengan pembelajaran yang akan dilaksanakan. Rencana Pelaksanaan Pembelajaran (RPP) merupakan pedoman yang dibuat dan digunakan oleh seorang guru untuk melaksanakan kegiatan pembelajaran dengan tujuan agar pembelajaran menjadi lebih terarah (Ferywidyastuti, 2015).

Pada (Tabel 2) indikator pencapaian kompetensi (IPK) pada RPP sistem imun kelas XI SMAN 2 Kuningan berada dalam kategori HOTS cukup baik. Indikator pada RPP tersebut bukan turunan dari KD 3 dan KD 4, hal ini dapat dilihat dari KKO yang digunakan dalam KD 3 adalah C4 (Menganalisis), sedangkan guru masih banyak menggunakan KKO pada level rendah (LOTS) diantaranya C2 (Memahami) dengan KKO menjelaskan. Pada KD 4 menggunakan KKO C3 (Melakukan) dan guru membuat indikator yang setara dengan KD 4, sedangkan indikator yang memuat KKO HOTS ditemukan hanya terdapat 2 indikator dengan KKO menganalisis (C4). Indikator pencapaian kompetensi didapatkan dari hasil turunan Kompetensi Dasar (KD). Guru memiliki kewajiban untuk mengembangkan KD menjadi indikator-indikator pembelajaran yang kemudian akan dikembangkan lagi menjadi tujuan pembelajaran. Dalam pembuatan indikator pembelajaran atau IPK, guru harus mampu mengembangkan kompetensi minimum (KD) yang harus dicapai. Indikator yang dibuat harus berupa turunan dari KD atau minimal setara dengan KD. Guru memiliki tanggung jawab dalam mengembangkan KD menjadi indikator pembelajaran (Sulistiawan et al., 2017).

Tujuan pembelajaran berada dalam kategori HOTS cukup baik, yaitu kata kerja operasional (KKO) pada tujuan pembelajaran sama dengan kata kerja operasional (KKO) pada indikator pembelajaran. KKO yang digunakan guru dalam merumuskan tujuan pembelajaran lebih rendah dari KKO KD. KKO tujuan pembelajaran masih didominasi dengan KKO LOTS (C1-C3). Tujuan pembelajaran yang berbasis HOTS pada RPP guru biologi kelas XI SMAN 2 Kuningan diantaranya memuat KKO HOTS (C4-C6), tujuannya untuk menyesuaikan dengan kompetensi minimum yang harus dicapai, dan memberikan persiapan bagi siswa dalam menghadapi penilaian akhir pembelajaran. Dalam penyusunan tujuan pembelajaran, guru harus memperhatikan tingkatan kata kerja operasional yang digunakan. Kata kerja operasional dalam 
tujuan pembelajaran harus lebih tinggi dari KD atau minimal setara dengan KD. Tujuan pembelajaran yang berbasis HOTS harus melatih siswa untuk memecahkan permasalahan, menemukan solusi, dan menciptakan suatu hal yang berkaitan dengan pemecahan masalah (Rizaldi, 2020).

Materi ajar pada RPP guru biologi kelas XI SMAN 2 Kuningan berada dalam kategori HOTS baik, yaitu guru sudah mencantumkan uraian materi yang sesuai dengan KD dan indikator, guru menguraikan materi menjadi beberapa pokok bahasan yang terdapat dalam KD sesuai dengan rincian indikator. Dalam menyusun materi ajar, guru terlebih dahulu harus mampu membuat indikator pencapaian kompetensi dan tujuan pembelajaran dari hasil pengembangan kompetensi dasar. Indikator dan tujuan pembelajaran hasil dari pengembangan kompetensi dasar selanjutnya dikembangkan menjadi cakupan materi ajar yang akan dicantumkan dalam RPP dan disampaikan kepada siswa dikelas (Indaryanti et al., 2019).

Materi yang disusun oleh guru biologi kelas XI SMAN 2 Kuningan bersifat kontekstual sehingga dapat dihubungkan dengan kehidupan sehari-hari. Guru dapat menjelaskan materi dengan memberikan contoh yang nyata sehingga siswa memiliki gambaran yang jelas terkait materi yang dijelaskan. Materi ajar yang bersifat kontekstual dapat memudahkan siswa menangkap dan memahami materi yang dijelaskan oleh guru. Guru mencantumkan materi dalam RPP sistem imun secara garis besar yang merupakan rincian dari indikator dan KD. Guru mencantumkan materi yang akan dibahas dalam bentuk konsep. Dalam menyusun materi ajar, guru harus merinci materi menjadi beberapa bagian, diantaranya fakta, konsep, prinsip, dan prosedural (Hanisa et al., 2018).

Model dan metode pembelajaran yang digunakan oleh guru berkategori baik. Model dan metode pembelajaran yang dicantumkan sesuai dengan kurikulum 2013. Dalam Kurikulum 2013 menuntut pembelajaran menggunakan model dan metode yang berbasis masalah dan menuntut siswa untuk dilatih berpikir. Model pembelajaran yang digunakan sudah memuat aspek keterampilan berpikir tingkat tinggi karena sudah menggunakan model pembelajaran Discovery Learning (DL). Discovery Learning merupakan Model pembelajaran yang melatih siswa untuk terlibat aktif dalam kegiatan pembelajaran, sehingga mereka diberikan kesempatan untuk mengembangkan ide dalam memecahkan permasalahan, sehingga menambah pengetahuan dan pengalaman belajar mereka (Yuliana, 2019). 
Metode pembelajaran yang dicantumkan oleh guru dalam RPP sistem imun adalah tanya jawab, wawancara, diskusi dan bermain peran. Dalam melaksanakan pembelajaran, guru mencantumkan beberapa metode pembelajaran, diantaranya diskusi dan metode tanya jawab. Metode diskusi dapat dilakukan dalam pembelajaran untuk melatih siswa berkolaborasi dengan siswa lain, melatih siswa bertukar pendapat, ide dan bersama-sama mencari solusi untuk menyelesaikan soal permasalahan. Metode tanya jawab dapat melatih siswa aktif dikelas dengan diberikan kesempatan untuk memberikan pertanyaan dan menjawab pertanyaan yang diberikan oleh guru (Sulistiawan et al., 2017).

Media pembelajaran pada RPP guru biologi kelas XI SMAN 2 Kuningan berada dalam kategori sangat baik, guru sudah mengikuti perkembangan IPTEK. Guru sudah menggunakan teknologi dalam menyampaikan pembelajaran, yaitu menggunakan laptop, infocus, dan LCD proyektor. Media yang digunakan memfasilitasi penerapan pendekatan saintifik serta memudahkan penerapan model pembelajaran. Media LKS yang digunakan oleh siswa berdasarkan pada model pembelajaran yang digunakan, sehingga media sesuai dengan model pembelajaran. Media pembelajaran harus disediakan oleh guru dalam melaksanakan pembelajaran, karena melalui media pembelajaran guru dapat menyampaikan materi yang akan disampaikan. Media pembelajaran memiliki peran yang sangat penting dalam proses belajar mengajar dikelas dan dapat dijadikan sebagai alat untuk memberikan rangsangan kepada siswa untuk belajar. Melalui media pembelajaran, siswa dapat dengan mudah memahami materi sehingga penyampaian materi dalam rencana pembelajaran dapat tersampaikan (Tafonao, 2018).

Lembar Kerja Siswa (LKS) pada RPP guru biologi kelas XI SMAN 2 Kuningan pada sistem imun berada dalam kategori cukup baik. LKS sudah memfasilitasi siswa untuk mencapai tujuan pembelajaran dan berkaitan dengan RPP baik dari segi konten dan proses kognitif. Namun, tidak semua soal-soal yang terdapat dalam LKS memuat aspek HOTS, artinya tidak semua soal berisi soal-soal permasalahan yang mampu memfasilitasi HOTS (C4-C6). KKO yang digunakan oleh guru masih didominasi oleh KKO LOTS (C1-C3). Dalam pembuatan soal, guru masih mendominasi KKO LOTS (C1-C3). Penggunaan KKO HOTS (C4-C6) masih sedikit digunakan oleh guru. Soal yang baik adalah soal yang berisi permasalahan yang membutuhkan penyelesaian dan harus ditemukan solusi (Gusnawati \& Anwar, 2020). Lembar Kerja Siswa (LKS) yang dibuat oleh guru bertujuan untuk membimbing siswa dalam melaksanakan pembelajaran, hal ini sesuai dengan pendapat Lismaya (2018) bahwa penggunaan lembar kerja 
bertujuan untuk membimbing siswa selama pembelajaran berlangsung. Lembar kerja dapat digunakan untuk melatih kemampuan berpikir siswa dan memfasilitasi siswa untuk belajar (Lismaya, 2018).

Pada (Tabel 3) analisis perangkat pembelajaran yang kedua adalah analisis pelaksanaan pembelajaran yang dilaksanakan secara daring oleh guru biologi kelas XI SMAN 2 Kuningan melalui aplikasi CloudX disekolah. Pelaksanaan pembelajaran meliputi 3 tahapan, yaitu kegiatan pendahuluan, kegiatan inti, dan kegiatan penutup. Pada kegiatan pendahuluan pembelajaran yang dilaksanakan oleh guru biologi kelas XI SMAN 2 Kuningan berkategori sangat baik. Hasil analisis observasi pelaksanaan pembelajaran pada tanggal 24 April, 03 dan 06 April 2021 diawali dengan guru mempersiapkan kondisi awal pembelajaran melalui aplikasi CloudX. Pada kegiatan pendahuluan guru melakukan orientasi dengan memberikan salam, menanyakan kabar dan mengecek kehadiran siswa yang sudah masuk kelas daring.

Guru biologi kelas XI SMAN 2 Kuningan melakukan kegiatan apersepsi dengan mengaitkan pembelajaran minggu lalu dengan materi yang akan dipelajari pada hari ini yaitu dengan mengaitkan materi sistem reproduksi dengan materi sistem imun. Guru juga memberikan motivasi dan apersepsi kepada siswa. Dalam kegiatan pendahuluan, guru melakukan kegiatan apersepsi dan menyampaikan tujuan pembelajaran mengenai materi yang akan dibahas pada hari ini (Hanisa et al., 2018).

Dalam kegiatan pendahuluan di kelas daring, guru biologi kelas XI SMAN 2 Kuningan tetap menyampaikan tujuan pembelajaran dan rencana pembelajaran yang akan dilaksanakan pada hari itu secara lisan dengan ringkas. Penyampaian tujuan dan rencana pembelajaran bertujuan untuk memberikan pemahaman kepada siswa mengenai tujuan dari dilaksanakannya pembelajaran pada hari itu. Dalam kegiatan pendahuluan pembelajaran, guru menyampaikan tujuan pembelajaran, dan memberikan apersepsi (Susmiati, 2020).

Pada kegiatan inti berada dalam kategori sangat baik. Pada kegiatan inti, guru biologi kelas XI SMAN 2 Kuningan menggunakan model pembelajaran yang berbasis masalah dan metode pembelajaran tanya jawab. Dalam kegiatan inti pembelajaran, guru mempersiapkan model pembelajaran, metode pembelajaran, sumber belajar, dan media pembelajaran yang akan digunakan dikelas. Pembelajaran yang memfasilitasi keterampilan berpikir tingkat tinggi diantaranya dengan menggunakan model pembelajaran yang berbasis masalah, metode 
pembelajaran yang melibatkan siswa aktif dalam pembelajaran dan media pembelajaran yang dapat memudahkan guru menyampaikan materi ajar (Febrina, 2018).

Pada tahap inti tanggal 24 April 2021 guru menggunakan model Discovery Learning dengan memberikan stimulasi berupa suatu artikel atau wacana mengenai HIV/AIDS yang ditampilkan melalui Power Point. Power Point ini berisi cakupan materi yang telah disusun oleh guru mengenai materi sistem imun dan ditampilkan oleh guru dalam aplikasi CloudX ketika pembelajaran berlangsung. Siswa dapat melihat dan mengamati materi yang disampaikan oleh guru walaupun dalam keadaan daring. Untuk menyampaikan materi pembelajaran, guru menggunakan media Power Point karena dinilai lebih efektif dan efisien dalam membantu guru menyampaikan materi pembelajaran dikelas . Pembelajaran menerapkan pendekatan saintifik, yaitu adanya kegiatan mengamati, menanya,mengumpulkan data, mengolah data, dan mengkomunikasikan. Dalam pembelajaran, guru menerapkan pendekatan saintifik yang mencakup kegiatan mengamati, menanya, mengumpulkan data, mengolah data, dan mengkomunikasikan (Sulistiawan et al., 2017).

Kegiatan penutup berada dalam kategori sangat baik, Kegiatan penutup yang dilaksanakan pada tanggal 24 April 2021 guru memberikan penugasan kepada peserta didik untuk menyelesaikan lembar kerja yang belum terselesaikan, dan tugas dikirim melalui E-mail guru. Guru dan siswa bersama-sama membuat kesimpulan tentang pembelajaran materi sistem imun pada hari ini. Guru biologi kelas XI SMAN 2 Kuningan melakukan penilaian berupa kehadiran siswa selama pembelajaran, guru memeriksa kehadiran di awal dan akhir pembelajaran. Guru menutup pembelajaran dengan mengucapkan terima kasih kepada peserta didik yang telah mengikuti pembelajaran dan mengucapkan salam. Pada kegiatan penutup pembelajaran, guru melakukan kegiatan evaluasi, membuat kesimpulan, dan melaksanakan tindak lanjut atau memberikan penugasan (Hanisa et al., 2018). Dalam kegiatan penutup pembelajaran, guru melaksanakan kegiatan tindak lanjut. Guru memberikan tugas dan memberikan informasi mengenai rencana pembelajaran yang akan dilaksanakan berikutnya (Febrina, 2018).

Pada (Tabel 4) menjelaskan hasil analisis pada evaluasi pembelajaran yang berbasis HOTS. Karakteristik evaluasi pembelajaran yang disusun oleh guru biologi kelas XI SMAN 2 Kuningan memuat aspek kognitif (Menilai pengetahuan), aspek afektip (Menilai sikap), dan aspek psikomotorik (Menilai keterampilan). Guru biologi kelas XI SMAN 2 Kuningan sudah 
mengembangkan evaluasi pembelajaran dengan melaksanakan 3 ranah evaluasi pembelajaran yang dilengkapi dengan instrument evaluasi, dan melaksanakan kegiatan tindak lanjut pembelajaran yang meliputi kegiatan remedial dan kegiatan pengayaan. Evaluasi pembelajaran merupakan hal penting yang harus dilaksanakan dalam kegiatan pembelajaran. Evaluasi pembelajaran sangat penting dilaksanakan dalam pembelajaran, hal ini dikarenakan evaluasi pembelajaran merupakan tahap akhir dari proses pembelajaran yang telah dilaksanakan (Febriani et al., 2013).

Dengan adanya evaluasi pembelajaran, maka guru akan mengetahui hasil dan ketercapaian tujuan pembelajaran yang telah direncanakan sebelumnya. Soal evaluasi materi sistem imun berkategori cukup baik yang merupakan soal yang dibuat oleh guru dalam Penilaian Akhir Tahun (PAT). Guru membuat soal sebanyak 40 soal, dengan jenis soal pilihan ganda. Soal yang sudah memfasilitasi HOTS ditemukan sebanyak 6 soal yaitu soal nomor 10, 12, 15, 19, 33, dan 40. Hal ini menunjukkan bahwa guru sudah berusaha memfasilitasi HOTS siswa dimasa pandemi covid-19. Hal ini senada dengan hasil penelitian (Warju et al., 2020) bahwa soal yang dibuat oleh guru dalam bentuk pilihan ganda tidak semuanya mengandung aspek HOTS. Hal ini dilihat dari KKO yang digunakan oleh guru dalam pembuatan soal, KKO HOTS meliputi C4, C5 dan C6 sedangkan KKO LOTS meliputi C1, C2, dan C3.

Dari ke-6 soal tersebut siswa diarahkan untuk menganalisis, mengevaluasi, mencipta, dan bersifat kontekstual. Soal bersifat kontekstual jika berisi permasalahan yang dikaitkan dengan contoh yang ada di dunia nyata, kejadian sehari-hari, sehingga siswa akan lebih mudah memahami. Kontekstual merupakan hal yang memberikan gambaran nyata dalam kehidupan sehari-hari, sesuai dengan situasi kehidupan, dan contoh yang nyata yang kita alami (Andriani et al., 2020).

Nilai yang diperoleh oleh siswa dari hasil ujian PAT sangat bervariasi dan berkategori baik. Nilai KKM yang ditetapkan adalah 75, dan peneliti menemukan nilai siswa yang masih dibawah KKM. Siswa kelas XI SMAN 2 Kuningan terdiri dari 7 kelas, dengan masing-masing kelas terdiri dari 36 siswa. Jumlah keseluruhan siswa yang mendapatkan nilai diatas KKM adalah 135 dari 252 siswa dan siswa yang nilainya dibawah KKM berjumlah 117 orang siswa. Hal ini menunjukkan bahwa lebih banyak siswa yang nilainya diatas KKM, artinya siswa mampu mengerjakan soal PAT dengan baik dan mampu menyelesaikan permasalahan dari soal yang diberikan. Hal ini senada dengan hasil penelitian (Kairuddin, 2018) bahwa proses jawaban siswa 
dalam menyelesaikan soal permasalahan jauh lebih unggul dibandingkan dengan soal yang berbasis masalah. Siswa lebih mudah menyelesaikan soal yang berisi permasalahan, sehingga mereka diarahkan untuk membuat tanggapan, menilai, menganalisis, atau mengungkapkan ide yang mereka miliki untuk menyelesaikan permasalahan tersebut.

Teknik dan instrument evaluasi berada dalam kategori sangat baik. Guru sudah melakukan teknik penilaian yang dapat mengukur pengetahuan, sikap, dan keterampilan. Teknik penilaian pengetahuan dilakukan guru melalui kegiatan tes atau ujian. Hal ini sudah dilakukan oleh guru ketika pelaksanaan ujian Penilaian Akhir Tahun (PAT). Hal ini senada dengan hasil penelitian (Rosyidi, 2020) bahwa teknik penilaian kognitif yang dilakukan oleh guru adalah dalam bentuk tes tertulis. Bentuk tes tertulis yang diberikan oleh guru dapat berupa pilihan ganda yang memuat pertanyaan dengan diikuti oleh sejumlah alternative jawaban. Tujuan dari penilaian kognitif adalah untuk mengukur kemampuan berpikir siswa, diantaranya dalam memecahkan masalah,menyelesaikan suatu permasalahan, atau hal-hal yang memerlukan ide atau tanggapan. Instrument penilaian pengetahuan berupa soal evaluasi yang bertujuan untuk mengukur tingkat ketercapaian tujuan pembelajaran yang telah dilaksanakan. Guru melengkapi instrument penilaian pengetahuan dengan lembar penilaian yang berisi daftar nilai siswa hasil dari PAT.

Teknik penilaian sikap yang dilaksanakan oleh guru ketika pelaksanaan pembelajaran yaitu dengan menilai kehadiran siswa. Dalam pembelajaran daring, guru tetap menilai sikap siswa selama pembelajaran berlangsung diantaranya bekerjasama, jujur dalam mengerjakan tugas dan dalam berkata. Sikap bertanggung jawab dalam menyelesaikan tugas dan mengikuti pembelajaran, serta sikap disiplin selama pembelajaran berlangsung. Sikap siswa yang dapat dinilai dengan penilaian afektip diantaranya adalah kejujuran, disiplin, sikap tanggungjawab, percaya diri, dan lain sebagainya. Instrument penilaian sikap yang digunakan oleh guru berupa lembar penilaian yang berisi tabel nilai dan dilengkapi dengan aspek yang dinilai. Guru mencantumkan 6 aspek yang dinilai, yaitu berdoa sebelum memulai pelajaran, mengucapkan salam sebelum berbicara, bekerjasama, jujur, bertanggungjawab, jujur, tanggung jawab, dan disiplin. Penilaian afektip oleh guru dengan mengamati sikap siswa pada saat proses pelajaran berlangsung, guru akan menilai dengan menggunakan lembar instrument yang telah dipersiapkan dan disesuaikan oleh guru tersebut (Muslich,2014).

Penilaian psikomotorik dilaksanakan oleh guru dengan menilai keaktifan siswa dikelas, diantaranya keaktifan bertanya dan menjawab. Guru pun menilai tingkat penguasaan materi 
siswa ketika mereka ditanya atau menjawab pertanyaan, serta kemampuan mereka dalam menyelesaikan masalah contohnya dalam soal LKS yang diberikan. Guru tetap memberikan penilaian yang mengarah pada pengetahuan, sikap, dan keterampilan walaupun dalam keadaan pembelajaran daring. Hal ini senada dengan hasil penelitian (Nurjanah, 2019) bahwa penilaian psikomotorik yang dilakukan pada proses pembelajaran meliputi keterampilan yang dimiliki siswa. Segala tingkah laku, perbuatan, dan penampilan siswa dapat dikategorikan dalam penilaian psikomotorik. Penilaian ini dilakukan dengan mengamati perilaku dan keterampilan siswa selama pembelajaran dilaksanakan. Instrument penilaian psikomotorik yang digunakan oleh guru berupa lembar penilaian yang berisi tabel nilai dan dilengkapi dengan aspek yang dinilai. Dalam lembar penilaian psikomotorik, guru mencantumkan 8 aspek yang dinilai, yaitu kesesuaian respon dengan pertanyaan, kesesuaian pemilihan kata, kesesuaian penggunaan tata bahasa, pelapalan, penguasaan materi diskusi, kemampuan menjawab pertanyaan, kemampuan mengolah kata, dan kemampuan menyelesaikan masalah.

Keterlaksanaan evaluasi berada dalam kategori sangat baik. Pelaksanaan tes tertulis dilaksanakan dengan baik dan terjadwal pada hari yang telah ditentukan. Hal ini sesuai dengan pernyataan dalam Permendikbud Nomor 66 Tahun 2013 bahwa ulangan semester (Penilaian Akhir Tahun) dilaksanakan oleh pendidik dibawah koordinasi satuan pendidikan. Pelaksanaan tes tertulis yang dianalisis oleh peneliti adalah kegiatan Penilaian Akhir Tahun (PAT) yang dilaksanakan pada tanggal 07-11 Juni 2021 di SMAN 2 Kuningan. Pelaksanaan ujian PAT dilaksanakan secara daring, guru menggunakan aplikasi yang sudah disediakan oleh sekolah untuk memberikan soal kepada siswa. Guru merancang soal ujian dengan disertai kunci jawaban, jika siswa sudah selesai mengisi soal, maka akan secara otomatis akan langsung ternilai. Hasil ini senada dengan pendapat Kunandar (2013) dalam Norlaila (2015) bahwa pelaksanaan evaluasi pembelajaran sudah diatur dan ditetapkan dalam prosedur pembelajaran (Norlaila, 2015).

Kegiatan tindak lanjut berada dalam kategori baik. Guru mengadakan kegiatan tindak lanjut pembelajaran, diantaranya adalah kegiatan remedial. Siswa yang nilainya kurang dari KKM (75) akan diberikan kesempatan untuk mengikuti kegiatan remedial. Kegiatan remedial merupakan kegiatan pembelajaran yang berkaitan dengan perbaikan. Remedial bertujuan untuk membantu siswa dalam menuntaskan program belajar dengan upaya memberikan tambahan waktu diluar jam pelajaran (Izzati, 2015). Kegiatan ini dilakukan untuk siswa yang memiliki nilai dibawah rata-rata, atau kurang dari kriteria nilai yang telah ditetapkan (KKM). Kegiatan 
remedial ditujukan untuk diikuti oleh siswa yang nilainya belum mencapai KKM, dan belum mencapai tujuan pembelajaran yang telah ditentukan. Kegiatan remedial sangat membantu siswa untuk mencapai tujuan pembelajaran dan kriteria nilai yang telah ditetapkan (Lidi, 2018).

Pada kegiatan pengayaan guru memberikan tugas mandiri untuk dipelajari dirumah oleh siswa. Kegiatan pengayaan ini dilakukan bagi siswa yang telah memenuhi kriteria nilai yang ditelah ditetapkan atau sudah mencapai KKM. Guru memberikan tugas untuk membuat kesimpulan mengenai materi yang telah dipelajari dan materi yang akan dipelajari (Hasibuan \& Aisiah, 2020). Dari data keterlaksanaan kegiatan tindak lanjut pembelajaran didapatkan hasil bahwa melalui kegiatan remedial mengharuskan siswa belajar lebih rajin agar mendapatkan nilai yang sesuai dengan KKM. Pada kegiatan pengayaan, siswa dilatih untuk mempelajari dan melakukan kajian literasi pada materi yang akan dipelajari dipertemuan selanjutnya.

\section{KESIMPULAN DAN SARAN}

\section{Kesimpulan}

Dari hasil analisis perangkat pembelajaran daring materi sistem imun kelas XI SMAN 2 Kuningan dapat disimpulkan bahwa Rencana Pelaksanaan Pembelajaran (RPP) sudah berbasis higher order thinking skill (HOTS), di masa pandemi covid-19 dengan kategori baik. Pelaksanaan pembelajaran sudah berbasis higher order thinking skill (HOTS) di masa pandemi covid-19 dengan kategori sangat baik. Evaluasi pembelajaran sudah berbasis higher order thinking skill (HOTS) di masa pandemi covid-19 dengan kategori baik.

\section{Saran}

Untuk saat ini pembelajaran dilaksanakan secara daring, sedangkan tuntutan kurikulum semakin berkembang untuk melatih keterampilan berpikir tingkat tinggi siswa dalam pembelajaran. Hal ini bukan menjadi alasan guru untuk tidak memfasilitasi HOTS kepada siswa dalam pembelajaran. Guru harus tetap memfasilitasi HOTS siswa dengan menerapkannya pada RPP, proses pembelajaran, dan evaluasi pembelajaran dikelas daring. Dengan adanya tuntutan kurikulum dan semakin pesatnya dunia pendidikan, diharapkan guru tetap konsisten dalam memfasilitasi HOTS siswa melalui perangkat pembelajaran yang disusun dan dipersiapkan oleh guru, terlebih dalam materi biologi yang mana biasanya siswa diarahkan oleh guru untuk menganalisis suatu proses atau kejadian tertentu yang terjadi dilingkungan sekitar. 


\section{DAFTAR RUJUKAN}

Anderson,L.W.,\& Krathwohl,D.R.(2015).Kerangka Landasan untuk Pembelajaran,Pengajaran, dan Asesment (terjemahan).Yogyakarta : Pustaka Pelajar.100-133.

Ariyana,Y., Pudjiastuti,A.,Bestary, R., \& Zamroni.(2018).Buku Pegangan Pembelajaran Berorientasi pada Keterampilan Berpikir Tingkat Tinggi.Jakarta : Direktorat Jenderal Guru dan Tenaga Kependidikan (Ditjen GTK).7-13.

Andriani, Supriyatman, \& Muslimin. (2020). Analisis Soal Higher Order Thinking Skills ( HOTS ) Bentuk Essay yang dibuat oleh Guru Fisika SMA di Kota Palu. Jurnal Pendidikan Fisika Tadulako Online (JPFT), 8(2), 95-98.

Febriani, W. D., Sidik, G. S., \& Zahrah, R. F. (2013). ANALISIS PENGELOLAAN EVALUASI PEMBELAJARAN KURIKULUM 2013 DI SEKOLAH DASAR. Jurnal Tunas Bangsa, 7(1), 60-72.

Febrina, D. (2018). STUDI TENTANG PELAKSANAAN PEMBELAJARAN GEOGRAFI BERDASARKAN STANDAR PROSES DI SMA NEGERI 7 PADANG. Jurnal Buana, 2(1), 338-349.

Ferywidyastuti, S. (2015). PENGEMBANGAN RENCANA PELAKSANAAN PEMBELAJARAN MENGGUNAKAN JIGSAW BERBASIS KARAKTER UNTUK MENINGKATKAN AKTIVITAS MAHASISWA. The 2nd University Research Coloquium 2015, 325-335.

Gusnawati, Y., \& Anwar, S. (2020). ANALISIS LEVEL SOAL ULANGAN AKHIR SEMESTER (UAS) SEMESTER GENAP TAHUN PELAJARAN 2018/2019 MATA PELAJARAN GEOGRAFI SMA/MA DI KOTA PADANG. Jurnal Buana, 4(1), 91-101.

Hadisi, L., \& Muna, W. (2015). Pengelolaan Teknologi Informasi dalam Menciptakan Model Inovasi Pembelajaran (E-Learning). Jurnal Al-Ta'dib, 8(1), 117-140.

Hanisa, Syamwil, \& Susanti, D. (2018). Implementasi Kurikulum 2013 Pada Mata Pelajaran Ekonomi Di Sma Negeri Di Kotapadang (Tinjauan Rencana Pelaksanaan Pembelajaran). Jurnal Ecogen, 1(2), 371. https://doi.org/10.24036/jmpe.v1i2.4757

Hasibuan, A. Z., \& Aisiah. (2020). Pelaksanaan Remedial dan Pengayaan dalam Pembelajaran Sejarah di SMA A Kota Padang. Jurnal Pendidikan Tambusai, 4(1), 434-444.

Helmawati.(2019).Pembelajaran dan Penilaian Berbasis HOTS.Bandung : PT Remaja Rosdakarya.158.

Indaryanti, Susanti, E., Aisyah, N., \& Scristia. (2019). Analisis Kesesuaian Indikator terhadap Kompetensi Dasar pada Pelajaran Matematika oleh Guru Sekolah Menengah Palembang. Jurnal Gantang, 4(2), 103-109. https://doi.org/10.31629/jg.v4i2.1429

Izzati, N. (2015). Pengaruh Penerapan Program Remedial dan Pengayaan Melalui Pembelajaran 
Tutor Sebaya Terhadap Hasil belajar Matematika Siswa. EduMa, 4(1), 55-68.

Kairuddin. (2018). Analisis Proses Jawaban Siswa Terkait Kemampuan Pemecahan Masalah pada Kelas Pembelajaran Kontekstual dan Kelas Pembelajaran Berbasis Masalah pada Siswa SMPN 1 Salapian. Jurnal Inspiratif, 4(1), 101-111.

Kunandar. (2013).Penilaian Autentik : Penilaian Hasil Belajar Peserta Didik Berdasarkan Kurikulum 2013. Jakarta : PT. Raja Grafindo Persada.

Lidi, M. W. (2018). PEMBELAJARAN REMEDIAL SEBAGAI SUATU UPAYA DALAM MENGATASI KESULITAN BELAJAR. Foundasia, IX(1), 15-26.

Lismaya, L. (2018). PENGGUNAAN LKM BERBASIS MASALAH PADA OUTDOOR ACTIVITIES UNTUK MENINGKATKAN MULTIPLE Intelligences mahasiswa. Quagga: Jurnal Pendidikan Dan Biologi Volume, 10(1), 71-78. https://doi.org/10.25134/quagga.v10i01.874.Abstrak

Majid, Abdul.(2013).Perencanaan Pembelajaran.Bandung : PT Remaja Rosdakarya.15.

Muslich, Muhammad.(2014).Pengembangan Model Assessment Afektif Berbasis Self Assessment dan Peer Assessment di SMA Negeri 1 Kebomas.Jurnal Kebijakan dan Pengembangan Pendidikan.2(2).143-148.

Norlaila. (2015). Efektivitas Evaluasi Pembelajaran di Sekolah Dasar Islam Terpadu ( SDIT ) Ukhuwah Kota Banjarmasin. Taswir, 3(5), 99-116.

Nurjanah. (2019). Teknik dan Instrumen Asesmen Ranah Psikomotorik Pada Pendidikan Anak Usia Dini. JurnalAL_Athfal, 2(2), 45-61.

Permendikbud.(2013).Permendikbud Nomor 66 Tahun 2013 Tentang Standar Penilaian Pendidikan.Jakarta : Kemendikbud

Rizaldi, S. R. (2020). Analisis Materi dan Tujuan Pembelajaran pada Materi Listrik Dinamis. Jurnal Pendidikan MIPA Volume, 10(2), 60-64.

Rosyidi, D. (2020). Teknik dan Instrumen Asesmen Ranah Kognitif. Tasyri, 2(April), 1-13.

Sari, N. M., Sabri, T., Kresnadi, H., Keguruan, F., Pendidikan, I., \& Pontianak, U. T. (2020). Analisis perangkat pembelajaran tematik dengan pendekatan saintifik dalam masa covid-19 di kelas iv sd. Jurnal Pendidikan Dan Pembelajaran Khatulistiwa, 9(11), 1-8.

Setiawati, I., \& Hindriana, A. F. (2020). JPBIO ( Jurnal Pendidikan Biologi ). JPBIO ( Jurnal Pendidikan Biologi ), 5(1), 1-11. https://doi.org/10.31932/jpbio.v5i1.531

Setyorini, D.,\& Izzati, R. E.(2016).Pengembangan Perangkat Pembelajaran untuk Meningkatkan Motivasi Belajar dan Karakter Bersahabat Siswa Kelas IV SD.Jurnal Prima Edukasia.4(2).120-133.

Sidik, D. C. N., Jamali, \& Rodisin, D. N. (2021). Peran Guru Sebagai Fasilitator pada Sistem Pembelajaran Jarak Jauh di Era Pandemi COVID-19 di SMP NEGERI 1 KUNINGAN dan SMA NEGERI 2 KUNINGAN. My Campaign Journal, 3(1), 1-13. 
Sulistiawan, M. J., Yulistio, D., \& Arifin, M. (2017). Pelaksanaan Pembelajaran Bahasa Indonesia Kurikulum 2013 Di Kelas Xi Sma Negeri 2 Kota Bengkulu. Jurnal Ilmiah KORPUS, 1(1), 101-106. https://doi.org/10.33369/jik.v1i1.3276

Sugiyono.(2015).Metode Penelitian Kuantitatif,Kualitatif dan R\&D.Bandung : Alfabeta.hal.283377.

Susmiati, E. (2020). Meningkatkan Motivasi Belajar Bahasa Indonesia Melalui Penerapan Model Discovery Learning dan Media Video Dalam Kondisi Pandemi Covid-19 bagi Siswa SMPN 2 Gangga. Jurnal Paedagogy: Jurnal Penelitian Dan Pengembangan Pendidikan, 7(3), 210-215.

Tafonao, T. (2018). Peranan Media Pembelajaran Dalam Meningkatkan Minat Belajar $\begin{array}{llll}\text { Mahasiswa. Jurnal Komunikasi Pendidikan, } & 2(2), & \end{array}$ https://doi.org/10.32585/jkp.v2i2.113

Warju, Ariyanto, S. R., Soeryanto, \& Trisna, R. A. (2020). Analisis Kualitas Butir Soal Tipe HOTS pada Kompetensu Sistem Rem di Sekolah Menengah Kejuruan. Jurnal Pendidikan Teknologi Dan Kejuruan, 17(1), 95-104.

Yuliana, N. (2019). Penggunaan Model Pembelajaran Discovery Learning Dalam Peningkatan Hasil Belajaran Siswa Di Sekolah Dasar. Pedagogi: Jurnal Ilmu Pendidikan, 18(2), 56. https://doi.org/10.24036/fip.100.v18i2.318.000-000 